\title{
Development of an Optimization Pipeline of Asymmetric PCR Towards the Generation of DNA Aptamer- A Guide for Beginners
}

\section{Tzi Shien Yeoh}

USM AMDI: Universiti Sains Malaysia Institut Perubatan dan Pengigian Termaju

\section{Andrew Anna}

USM AMDI: Universiti Sains Malaysia Institut Perubatan dan Pengigian Termaju

\section{Tang Thean Hock}

USM AMDI: Universiti Sains Malaysia Institut Perubatan dan Pengigian Termaju

\section{Marimuthu Citartan ( $\square$ citartan@usm.my )}

USM AMDI: Universiti Sains Malaysia Institut Perubatan dan Pengigian Termaju https://orcid.org/0000-0001-5395-0040

\section{Research Article}

Keywords: asymmetric PCR, biotin-streptavidin-based separation, lambda exonuclease digestion, ssDNA.

Posted Date: October 25th, 2021

DOI: https://doi.org/10.21203/rs.3.rs-1011795/v1

License: (9) This work is licensed under a Creative Commons Attribution 4.0 International License. Read Full License

Version of Record: A version of this preprint was published at World Journal of Microbiology and Biotechnology on January 6th, 2022. See the published version at https://doi.org/10.1007/s11274-02103209-w. 
Development of an optimization pipeline of asymmetric PCR towards the generation of DNA aptamer- a guide for beginners

Tzi Shien Yeoh ${ }^{1}$, Andrew Anna ${ }^{1,2}$, Thean-Hock Tang ${ }^{1}$, Marimuthu Citartan ${ }^{1 \dagger}$

${ }^{1}$ Advanced Medical \& Dental Institute (AMDI), Universiti Sains Malaysia, Bertam, 13200 Kepala Batas, Penang, Malaysia

${ }^{2}$ Faculty of Medicine and Health Sciences, Universiti Malaysia Sarawak (UNIMAS), 93400 Kota Samarahan, Sarawak, Malaysia

†Address of correspondence: Marimuthu Citartan (citartan@usm.my) 


\section{Abstract:}

Asymmetric PCR is one of the most utilized strategies in ssDNA generation towards DNA aptamer generation due to its low cost, robustness and the low amount of starting template. Despite its advantages, careful optimization of the asymmetric PCR is still warranted to optimize the yield of ssDNA. In this present study, we have developed an extensive optimization pipeline that involves the optimization of symmetric PCR, optimization of primer amounts/ratios, PCR cycles, annealing temperatures, template concentrations, $\mathrm{Mg}^{2+} / \mathrm{dNTP}$ concentrations and the amounts of Taq Polymerase. To further boost the generation of ssDNA, we have also integrated an additional single-stranded DNA generation method via lambda exonuclease and biotin-streptavidin-based separation into the optimization pipeline to further improve the yield of ssDNA generation. We have acquired $700 \pm 11.3$ and $820 \pm 19.2 \mathrm{nM}$ for A-PCR-lambda exonuclease and A-PCR-biotin-streptavidin-based separation, respectively. We urge to develop a separate optimization pipeline of asymmetric PCR for each different randomized ssDNA library before embarking on any SELEX studies.

Keywords: asymmetric PCR, biotin-streptavidin-based separation, lambda exonuclease digestion, ssDNA.

\section{Introduction}

Having the ability to bind to their targets with high affinity and specificity like antibodies, aptamers are also dubbed as chemical antibodies. Aptamers fold into a 
myriad of three-dimensional (3D) structures, which are strengthened by hydrogenbonding, van der Waals forces and electrostatic charges to forge interaction with their cognate targets for the formation of aptamer-target complex [1-3]. Since their discovery in the early $1990[4,5]$, aptamers have gradually emerged as a promising class of molecular recognition element (MRE) on par with antibodies dues to the following features such as lower cost of synthesis, ability to undergo reversible denaturation and renaturation without the loss of binding capability and low-to-no immunogenicity. Apart from that, aptamers are more versatile than antibodies in term of target selectivity as evidenced in a number of aptamers generated against various targets which are small molecules, protein, viruses and even whole cells [6]. Moreover, compared to antibodies, versatility of aptamers also permits chemical modifications to be performed at ease for diagnostic and therapeutic applications [7, 8]. Aptamers are generated through a process called Systemic Evolution of Ligands via Exponential Enrichment (SELEX). Generally, SELEX is made up of four major steps, which are incubation of the randomized single-stranded DNA/ RNA (ssDNA or RNA) library with the target, partitioning and recovery of the target-bound nucleic acids, amplification of the target-bound nucleic acid molecules via Polymerase Chain Reaction (PCR) for DNA SELEX or Reverse-Transcription Polymerase Chain Reaction (RT-PCR) for RNA SELEX and lastly the regeneration of SSDNA/ RNA for the subsequent round of selection process.

DNA aptamers are preferred over RNA aptamers due to their stability. As DNA SELEX requires the generation of SSDNA, conversion of double-stranded DNA (dsDNA) to ssDNA is of utmost importance in determining the success of an in vitro selection process. Numerous techniques have been introduced [9]; biotinstreptavidin-based separation [10], lambda exonuclease digestion [11, 12], 
hexaethylene glycol-mediated separation on denaturing urea polyacrylamide gel electrophoresis and asymmetric PCR (A-PCR) [13, 14]. A-PCR is largely favoured due to its low cost, robustness and the ability to produce a high amount of ssDNA from a minimal input of dsDNA template. By using primers at skewed ratios, ssDNA is anticipated alongside dsDNA by virtue of logarithmic amplification followed by linear amplification. As a starting step prior to any SELEX experiment, optimization of an asymmetric PCR is vital to ensure an optimal production of ssDNA for the subsequent cycles of SELEX, as demonstrated by several previous studies. Tabarzad et al., 2014 have carried out optimization studies involving different annealing temperatures, number of amplification cycles, primer ratios and $\mathrm{Mg}^{2+}$ concentrations to find out the optimum parameters [14]. Our group have also optimized annealing temperatures and PCR cycles in order to maximize the yield of ssDNA of asymmetric PCR reaction. Another study was carried out by Heiat et al., 2017, whereby the group have optimized primer amounts, ratios, template concentrations, annealing temperatures and PCR cycles [15].

Despite optimization carried out in the previous asymmetric PCR studies, some parameters are often overlooked such as the optimization of the symmetric PCR reactions, the amount of Taq Polymerase and the concentration of $\mathrm{Mg}^{2+} / \mathrm{dNTP}$. Impelled by this issue, in the present study, we undertook an effort to develop a much more extensive optimization pipeline that involves the optimization of symmetric PCR, optimization of primer amounts/ratios, PCR cycles, annealing temperatures, template concentrations, $\mathrm{Mg}^{2+} / \mathrm{dNTP}$ concentrations and the amounts of Taq Polymerase. We have also integrated an additional single-stranded DNA generation method via lambda exonuclease and biotin-streptavidin-based separation into the optimization pipeline to further improve the yield of ssDNA generation. We 
propose this optimization pipeline as the first step that can be carried out before initiating any SELEX experiments to augment the yield of SSDNA produced in each SELEX cycle.

\section{Materials and Methods}

\section{Symmetric PCR amplification}

Symmetric PCR amplification was first carried out to prepare the dsDNA template for the A-PCR. A single-stranded DNA library containing randomized region of 40-mer flanked by two fixed primer hybridization regions (5'-ATCCAGAGTGACGCAGCAN40-TGGACACGGTGGCTTAGT-3') was used in this study. The primers used were unmodified forward primer (5'-ATCCAGAGTGACGCAGCA-3'), biotinylated reverse primer (5'-/Biosg/ACT AAG CCA CCG TGT CCA-3') and phosphorylated reverse primer (5'-/Phos/ACT AAG CCA CCG TGT CCA-3'), which were all purchased from Apical Scientific. All PCR reactions were performed in $100 \mu \mathrm{L}$ reaction mixture containing 1X PCR buffer [7.5 mM Tris- $\mathrm{HCl}(\mathrm{pH} 9.0), 5 \mathrm{mM} \mathrm{KCl}$ and $20 \mathrm{mM}$ (NH4)2SO4], $1.5 \mathrm{mM} \mathrm{MgCl}, 0.2 \mathrm{mM}$ of dNTPs and $2.5 \mathrm{U}$ DNA Taq polymerase (Biotools, Madrid, Spain). The amount of template used was $20 \mathrm{ng}$ and the PCR parameters were fixed as follow: an initial denaturation at $95^{\circ} \mathrm{C}$ for 180 s, followed by amplification cycles of 30 s denaturation at $95{ }^{\circ} \mathrm{C}, 30 \mathrm{~s}$ annealing at $55{ }^{\circ} \mathrm{C}, 30 \mathrm{~s}$ extension at $72{ }^{\circ} \mathrm{C}$ and final extension at $72{ }^{\circ} \mathrm{C}$ for $300 \mathrm{~s}$. The concentrations of primers were optimized with various amounts of both the forward and reverse primer (10 pmol, 20 pmol, 30 pmol, 40 pmol, 50 pmol, 60 pmol, 70 pmol, 80 pmol, 90 pmol and $100 \mathrm{pmol}$ ). The number of amplification cycles were also optimized (1 cycle to 6 cycles). PCR products were run on a $4 \%$ agarose gel containing $0.5 \mu \mathrm{L} / \mathrm{mL}$ in $1 \mathrm{X}$ TAE buffer (40 mM Tris-acetate, $1 \mathrm{mM}$ EDTA) followed by visualization of the PCR 
products on Gel Doc XR+ System (Bio-rad Laboratories, Hercules, USA). PCR products were subjected to PCR-clean up using Nucleospin Gel \& PCR Cleanup (Macherey-Nagel, Duren, Germany) according to the manufacturer's instructions and dissolved in $25 \mu \mathrm{L}$ of elution buffer $(5 \mathrm{mM}$ Tris- $\mathrm{HCl}, \mathrm{pH}$ 8.5). Nanodrop spectrophotometer was used to quantify the amount of recovered dsDNA PCR products.

\section{Asymmetric PCR (A-PCR)}

Asymmetric PCR (A-PCR) reactions were carried out under the similar conditions used in the symmetric PCR except for the different primer ratios of the forward primer to the reverse primer $(20: 0,20: 0.5,20: 1,20: 2,50: 1$ and 100:1). Apart from the primer ratios, different PCR cycles (10 cycles to 30 cycles), different annealing temperatures $\left(55.0^{\circ} \mathrm{C}, 55.7{ }^{\circ} \mathrm{C}, 56.9{ }^{\circ} \mathrm{C}, 58.7{ }^{\circ} \mathrm{C}, 61.1^{\circ} \mathrm{C}, 63.0^{\circ} \mathrm{C}, 64.2^{\circ} \mathrm{C}\right.$ and 65.0 $\left.{ }^{\circ} \mathrm{C}\right)$, different amounts of templates $(0.2 \mathrm{ng} / \mu \mathrm{L}, 0.4 \mathrm{ng} / \mu \mathrm{L}, 0.8 \mathrm{ng} / \mu \mathrm{L}$ and $1.6 \mathrm{ng} / \mu \mathrm{L})$, different concentrations of $\mathrm{MgCl}_{2} / \mathrm{dNTP}$ and different amounts of Taq Polymerase

$\mathrm{U}, 5.0 \mathrm{U}, 10.0 \mathrm{U}, 15.0 \mathrm{U}, 20.0 \mathrm{U}$ ) were also used to determine the optimum parameters. A-PCR products were analyzed using $4 \%$ agarose gel electrophoresis and visualized via Gel Doc XR+ System.

\section{A-PCR-biotin-streptavidin separation}

Following the A-PCR, the scaled-up reaction of up to $1 \mathrm{~mL}$ was subjected to biotinstreptavidin separation. First, the A-PCR product was subjected to Nucleospin Gel \& PCR Cleanup according to the manufacturer's instructions and dissolved in $100 \mu \mathrm{L}$ of $0.5 X$ Saline Sodium Citrate buffer, followed by incubation with Streptavidin MagneSphere ${ }^{\circledR}$ Paramagnetic Particles (Promega Corporation, Madison, USA. Briefly, $400 \mu \mathrm{L}$ of the bead suspension was aliquoted and transferred to a clean 1.5 
$\mathrm{mL}$ microcentrifuge tube. A magnet was used to sediment the magnetic particles while the storage buffer was removed. Next, the magnetic beads were then washed thrice with $0.5 \mathrm{X}$ Saline Sodium Citrate buffer followed byincubation with purified APCR product at room temperature for $15 \mathrm{~min}$. Following sedimentation of the magnetic beads using magnet, the resulting supernatant was collected. The supernatant was again subjected to Nucleospin Gel \& PCR Cleanup and dissolved in $50 \mu \mathrm{L}$ of $\mathrm{ddH}_{2} \mathrm{O}$. Finally, the amount of ssDNA was quantified using Nanodrop spectrophotometer.

\section{A-PCR-lambda exonuclease digestion}

In our second strategy, following the $1 \mathrm{~mL}$-scaled up A-PCR reaction, the resulting product was subjected to lambda exonuclease digestion. Phosphorylated reverse primer was used for the large-scale A-PCR before lambda exonuclease digestion. Upon completion of the A-PCR, the PCR mixtures were purified using Nucleospin Gel \& PCR Cleanup. Next, the purified product was dissolved in $44 \mu \mathrm{L}$ of $\mathrm{dd}_{2} \mathrm{O}$ and subjected to a fifty-microliter lambda exonuclease digestion reaction with the addition of $10 \mathrm{U}(10 \mathrm{U} / \mathrm{\mu l})$ of enzyme in a final concentration of $67 \mathrm{mM}$ glycine-KOH (pH9.4), $2.5 \mathrm{mM} \mathrm{MgCl}$, and $0.01 \%(\mathrm{v} / \mathrm{v})$ Triton $\mathrm{X}-100$. Digestion time was optimized for 15 $\min , 30 \mathrm{~min}, 45 \mathrm{~min}$ and $60 \mathrm{~min}$ followed by heat inactivation at $80{ }^{\circ} \mathrm{C}$ for $10 \mathrm{~min}$. The supernatant was again subjected to Nucleospin Gel \& PCR Cleanup and dissolved in $50 \mu \mathrm{L}$ of $\mathrm{ddH}_{2} \mathrm{O}$. Finally, the amount of ssDNA was quantified using Nanodrop spectrophotometer.

\section{Statistical analysis}

The performance of the symmetric PCR was represented by the intensity of the dsDNA band on the agarose gel, which was measured by densitometry analysis with 
the aid of ImageJ (http://rsb.info.nih.gov/nih-image/). Similarly, the performance of the asymmetric PCR was reflected by the intensity of the band that represents ssDNA, which migrates faster than that of dsDNA. The measured intensity was subjected to Shapiro-Wilk test, to test the nature of the data to assume Gaussian distribution. Following the normality test, the data was subjected to analysis of variance (ANOVA) followed by Tukey's post hoc. All the quantitative results were expressed as mean \pm standard deviation. All the experiments were performed in triplicates. T-test and ANOVA were performed using GraphPad Prism 9.0.0, with $\mathrm{P}<$ 0.05 considered to be statistically significant.

\section{Results}

\section{Optimization of symmetric PCR amplification}

Prior to the optimization of the A-PCR, symmetric PCR optimization was carried out. First, the effect of the number of PCR cycles on the production of dsDNA was examined. A total of six PCR reactions were prepared and subjected to 1 to 6 PCR cycles. A significant enhancement of the dsDNA band intensity was observed when the number of PCR cycles was increased up to $5(P<0.0001)$ (Figure 1a \& 1b). When the PCR cycle was further increased to 6 PCR cycles, there was no significant difference in the dsDNA band intensity between that of cycle 5 and 6 . From the smear intensity analysis, the smear intensity stemming from PCR amplification with 6 PCR cycles was significantly higher than that of cycle $5(P<0.001)$ and the rest of the other PCR cycles $(P<0.0001)$ (Figure 1a \&1c). However, the smear intensity between PCR reactions with 5 and 6 PCR cycles showed no significant difference. As such, 5 PCR cycles was selected as the optimum number of PCR cycles due to 
the much higher dsDNA band intensity than that of 4 PCR cycles $(P<0.0001)$. Insert Figure 1

Next, the optimization that involves the usage of the different amounts of PCR primers from 10 pmol to 100 pmol was carried out. From Fig. $\mathbf{2 a}$ and Fig. $\mathbf{2}$ b, it is evident that the production of dsDNA gradually increased with the increasing amount of primers (forward and reverse primers) up to 80 pmole $(P<0.0001)$. Further increase in the amount of primers up to $100 \mathrm{pmol}$ resulted in no significant improvement in the production of dsDNA. As such, the primer amount chosen was 80 pmol optimumdue to the highest production of dsDNA. Insert Figure 2

\section{The optimization of asymmetric PCR amplification}

The purified dsDNA template was subsequently used for the asymmetric PCR reactions. Several different parameters were optimized such as the annealing temperatures, primer ratios, the concentrations of DNA template, the amounts of Taq DNA Polymerase and the concentrations of $\mathrm{dNTP} / \mathrm{MgCl}_{2}$.

\section{Annealing temperatures}

Out of the 8 different annealing temperatures, the temperature of $56.9{ }^{\circ} \mathrm{C}$ was chosen as the best temperature as it resulted in a much higher ssDNA band intensity compared to that of $55.7^{\circ} \mathrm{C}(P<0.05), 55.0{ }^{\circ} \mathrm{C}(P<0.01), 58.7^{\circ} \mathrm{C}(P<0.01)$ and the rest of the temperatures $\left(61.1^{\circ} \mathrm{C}, 63.0^{\circ} \mathrm{C}, 64.2^{\circ} \mathrm{C}\right.$ and $\left.65.0^{\circ} \mathrm{C}\right)(P<0.0001)$ (Figure $3 a \& 3 b)$.

\section{Primer ratios}

Different primer ratios were used in the asymmetric PCR amplification, ranging from $20: 0,20: 0.5,20: 0.1,20: 2,50: 1$ and $100: 1$. The primer ratio of $50: 1$ accounted for the 
highest ssDNA band intensity in the asymmetric PCR reaction $(P<0.0001)$ (Figure 3c \& 3d). However, the band intensity showed no significant difference as compared to the band intensity resulted when the primer ratio of 100:1 was used for the APCR. Thus, the value 50:1 was regarded as the optimum primer ratio for the A-PCR reaction. Insert Figure 3

\section{Concentrations of DNA template}

Using different amounts $(0.2 \mathrm{ng} / \mu \mathrm{L}, 0.4 \mathrm{ng} / \mu \mathrm{L}, 0.8 \mathrm{ng} / \mu \mathrm{L}, 1.6 \mathrm{ng} / \mu \mathrm{L})$ of purified DNA template concentration, the highest concentration that gives the highest band intensity was $1.6 \mathrm{ng} / \mu \mathrm{L}(P<0.0001)$, which was determined as the best template concentration (Figure 4a \& 4b).

\section{PCR cycles}

A-PCR was also optimized in terms of the number of PCR cycles $(10,20$ and 30 PCR cycles). From the analysis, it is corroborated that 30 PCR cycles was the optimum number of cycles due to the highest dsDNA band intensity among all (Figure 4c \& 4d). Insert Figure 4

\section{Concentrations of $\mathrm{dNTP} / \mathrm{MgCl}_{2}$}

Five different final concentrations were used in the asymmetric PCR reaction. The concentrations were $0.2 \mathrm{mM} / 1.5 \mathrm{mM}, 0.4 \mathrm{mM} / 2.0 \mathrm{mM}, 0.6 \mathrm{mM} / 2.5 \mathrm{mM}, 0.8 \mathrm{mM} / 3.0$ $\mathrm{mM}$ and $1.0 \mathrm{mM} / 3.5 \mathrm{mM}$. There was no significant difference between the ssDNA band intensity of $0.2 \mathrm{mM} / 1.5 \mathrm{mM}$ and $0.4 \mathrm{mM} / 2.0 \mathrm{mM}$ concentration of dNTPs/MgCl -containing asymmetric PCR reactions. However, increasing the concentrations of $\mathrm{dNTPs} / \mathrm{MgCl}_{2}$ up to $0.6 \mathrm{mM} / 2.5 \mathrm{mM}, 0.8 \mathrm{mM} / 3.0 \mathrm{mM}$ and 1.0 $\mathrm{mM} / 3.5 \mathrm{mM}$ significantly reduces the intensity of the ssDNA band. The lowest 
concentrations that still produces the highest SSDNA band intensity was finally determined to be $0.2 \mathrm{mM}$ and $1.5 \mathrm{mM}$, respectively for $\mathrm{dNTP}$ and $\mathrm{MgCl}_{2}$ (Figure 5a $\& 5 b)$.

\section{Amounts of Taq DNA Polymerase}

Another parameter optimized was the amount of Taq DNA Polymerase. Out of the 5 different units $(2.5 \mathrm{U}, 5.0 \mathrm{U}, 10.0 \mathrm{U}, 15.0 \mathrm{U}$ and $20.0 \mathrm{U})$, the usage of $2.5 \mathrm{U}$ of Taq DNA Polymerase was able to produce the highest band intensity. No significant difference of band intensity was observed when $5.0 \mathrm{U}$ and $10.0 \mathrm{U}$ of Taq DNA Polymerase were used. However, adding 15.0 U and 20.0 U resulted in significantly lower band intensity $(P<0.01, P<0.0001)$ than that of $2.5 \mathrm{U}$ of Taq DNA Polymerase. Since the lowest amount of Taq Polymerase that gave the best amplification was $2.5 \mathrm{U}$, this was taken as the optimum amount for the A-PCR reaction (Figure 5c \& 5d). Insert Figure 5

\section{Time course analysis of Lambda Exonuclease digestion}

Time course analysis was carried out to optimize the optimal digestion time by lambda exonuclease enzyme. As short as $15 \mathrm{~min}$ is enough for complete digestion and there is no significant difference in the band intensity represented by SSDNA if the digestion time was extended up to 30,45 and 60 min (Figure $6 \mathbf{a} \& \mathbf{6 b}$ ). Insert Figure 6

The effect of the incorporation of the ssDNA generation step on the ssDNA intensity

The intensity of the band represented by ssDNA, generated by asymmetric PCRlambda exonuclease digestion is significantly higher than the band intensity of the 
ssDNA produced by asymmetric PCR alone $(P<0.0001)$ (Figure 7a). Equivalently, asymmetric PCR-biotin-streptavidin separation resulted in SsDNA with band intensity significantly higher than that of asymmetric PCR per se $(P<0.001)$ (Figure $7 \mathbf{b})$. Insert Figure 7

\section{The recovery of ssDNA}

The ssDNA generated from the asymmetric PCR, asymmetric PCR-biotinstreptavidin-mediated separation and asymmetric PCR-lambda exonuclease-based digestion was subjected to purification using gel extraction kit. The yields obtained from $1 \mathrm{~mL}$ PCR reaction was $450 \pm 10.2 \mathrm{nM}, 820 \pm 19.2 \mathrm{nM}$ and $700 \pm 11.3 \mathrm{nM}$, respectively for asymmetric PCR, asymmetric PCR-biotin-streptavidin-mediated separation and asymmetric PCR-lambda exonuclease-based digestion (Table 1). Insert Table 1

\section{Discussion}

Five PCR cycles and 80 pmoles of primers were chosen as the best amplification parameters in the symmetric PCR

DNA SELEX consists of incubation, partitioning, recovery, amplification of bound nucleic acids and generation of ssDNA for the next cycle of SELEX. An optimum symmetric PCR amplification plays a critical role in determining the success of a SELEX experiment, as it is required to amplify the minute amount of the targeteluted sequences to be used in the subsequent cycle of SELEX. An efficient amplification of the symmetric PCR is also instrumental to prepare an optimum dsDNA as the starting template for the asymmetric PCR amplification to ensure a high yield of ssDNA. Asymmetric PCR is a two-step procedure, whereby the initial exponential amplification of dsDNA is followed by arithmetic amplification of ssDNA, 
where transition from the former to the latter phase happens when the limiting primer has been exhausted. In the end of the reaction, ssDNA is produced alongside dsDNA. To expedite the first phase of the asymmetric PCR, template DNA 'feeded' into the reaction must be enough and of high purity to ensure an optimum amplification.

One of the major issues in the symmetric PCR amplification of the randomized single-stranded DNA library is overamplification. Overamplification is detrimental as it leads to the production of aberrant and spurious PCR products of different sizes, negatively affecting the entire SELEX experiment [13]. In a study conducted by Tolle and his colleagues, sequencing result of the nucleic acid pool from SELEX Cycle 8 revealed several other sequences of different lengths, made up of concatenated multiple forward or reverse primer binding regions, without any enrichment of target binders [16]. Hence, in this study, the effect of two main parameters, such as the amount of primer and the number of PCR cycles were optimized in the symmetric PCR amplification.

From our findings, extending the PCR cycles up to 6 cycles clearly resulted in the appearance of smeary bands. The intensity of the smeary band resulted by 6 PCR cycles is significantly higher than that of 5 PCR cycles. While there is no significant difference between the dsDNA band intensity between cycle 6 and cycle 5 , we decided that 5 PCR cycles is enough to produce the dsDNA amplicon prior to the asymmetric PCR amplification (Figure 1a \& 1b). Using higher number of PCR cycles could give way towards appearance of higher molecular weight PCR product as the nature of the amplification of single-stranded DNA library, which consists of millions of different sequences is different from that of the amplification of a single- 
target in a conventional PCR. The diversity of the sequences could complicate the amplification process as millions of different targets which vary in GC-content and the presence of a myriad of secondary structures assumed by these sequences could confound the nature of the amplification. Millions of sequences with different secondary structures could themselves also act as the template, causing the appearance of the higher molecular weight PCR product, which appear as smeary bands. Limiting the number of PCR cycles sufficient enough to produce dsDNA is the best strategy to minimize overamplification. Moreover, we have also optimized the amount of primer for the symmetric PCR and decided to choose an amount of 80 pmole, due to the highest dsDNA band intensity produced in comparison to the rest of the primer amounts (Figure 2a \& 2b). There is no significant difference in the dsDNA band intensity when 90 and 100 pmole primers were used. As such, the lowest amount of primer which is 80 pmole was determined as the optimum primer for an optimum production of dsDNA template.

\section{Optimization of the asymmetric PCR cycle}

Using the purified dsDNA template, the next step in the optimization pipeline is finding the best parameters to ensure the optimum production of SSDNA in the asymmetric PCR amplification. Parameters scrutinized in this study involves annealing temperatures, ratio of primers, concentrations of dsDNA template, number of PCR cycles, concentrations of $\mathrm{dNTP} / \mathrm{MgCl}_{2}$ and the amount of Taq DNA Polymerase.

The best annealing temperature chosen was $56.9^{\circ} \mathrm{C}$ while $50: 1$ was determined as the best primer ratio 
Our analysis on the annealing temperature revealed that $56.9{ }^{\circ} \mathrm{C}$ as the optimum temperature that could produce the best yield of ssDNA (Figure $\mathbf{3 a} \& \mathbf{3 b}$ ). Increasing the temperature beyond this value proved to be a futile effort as the yield of ssDNA dwindles. A high annealing temperature could debilitate the hybridization of the primers to the primer binding region, lowering the amplification efficiency. As such, the yield of the ssDNA is poor when the annealing temperature increases. Our findings are also in line with the annealing temperature analysis performed by Heiat et al., 2017, who have also discovered that temperature range between $55^{\circ} \mathrm{C}$ and $59{ }^{\circ} \mathrm{C}$ was the most suitable temperature for the amplification of ssDNA.

One of the most pivotal parameters to be optimized in an asymmetric PCR amplification is the primer ratio. We have tested several different primer ratios such as $20: 0,20: 0.5,20: 1,20: 2,50: 1$ and $100: 1$. The ratio of $50: 1$ promoted the best amplification of ssDNA, which is significantly higher than the rest of the primer ratios except for 100:1 (Figure 3a \& 3b). We have chosen 50:1 compared to 100:1 as less primers were consumed. Our result agreed with the findings by Heiat et al., 2017, who have also stated that 50:1 appeared to be the best primer ratio for the SELEX cycles from 2 cycles onward. As the second phase of the asymmetric PCR amplification is of arithmetic nature, a primer ratio as high as $50: 1$ would be able to promote the amplification as more primers are available to synthesize new molecules of ssDNA.

The number of PCR cycles and the initial amount of dsDNA template play a prominent role in the asymmetric PCR

The concentrations of DNA template were also subjected to optimization. Different concentrations of DNA template from $0.2,0.4,0.6$ and $1.6 \mathrm{ng} / \mathrm{uL}$ of DNA 
template was used. From Figure $\mathbf{4 a}$ and Figure $\mathbf{4 b}$, it is evidenced that the concentration of the DNA template of $1.6 \mathrm{ng} / \mathrm{uL}$ was the optimum value that could engender the highest ssDNA band intensity. The usage of more DNA template provides more starting material that would eventually thrive to give rise to ssDNA following exponential and arithmetic amplification.

Akin to symmetric PCR, the number of PCR cycles in an asymmetric PCR reaction should also be optimized to maximize the yield of ssDNA while minimizing overamplification. In this study, the asymmetric PCR was carried out using several different PCR cycles from 10 to 30 cycles. The best number of cycles was discovered to be 30 , based on the highest ssDNA band intensity (Figure 4c \& Figure 4d). Although there was a concomitant increase in the intensity of dsDNA band, the ssDNA can be selectively purified by gel extraction in the subsequent step. Nevertheless, the most significant issue is the appearance of smeary band, which should be suppressed as much as possible so as not to complicate the selective purification of ssDNA. In this study, despite increasing the PCR cycles up to 30 , no smeary bands were produced. Our findings contradict the optimization result from other studies Tabarzad et al., 2014, Heiat et al., 2017 and even our previous study, which strongly suggests the need for optimization of each individual library prior to the selection of the best parameters for asymmetric PCR amplification.

Optimizing the concentrations and the amount of $\mathrm{dNTP} / \mathrm{MgCl}_{2}$ and Taq Polymerase, respectively resulted in no significant improvement in the amount of SsDNA

Using various concentrations of $\mathrm{dNTP} / \mathrm{MgCl}_{2}$ from $0.2 \mathrm{mM} / 1.5 \mathrm{mM}, 0.4$ $\mathrm{mM} / 2.0 \mathrm{mM}, 0.6 \mathrm{mM} / 2.5 \mathrm{mM}, 0.8 \mathrm{mM} / 3.0 \mathrm{mM}$ and $1.0 \mathrm{mM} / 3.5 \mathrm{mM}$. A standard 
$\mathrm{dNTP} / \mathrm{MgCl}_{2}$ concentration of $0.2 \mathrm{mM} / 1.5 \mathrm{mM}$ was sufficient for an optimum amplification, based on the highest ssDNA band intensity (Figure 5a and Figure 5b). We have also investigated the effect of different amounts of Taq Polymerase on the ssDNA production of the asymmetric PCR. No significant difference in the ssDNA band intensity was found when 2.5 units, 5 units and 10 units of Taq DNA polymerase was used (Figure 5a and Figure 5b). However, increasing the amount of Taq DNA polymerase caused the reduction in the band intensity of the ssDNA. We reckoned that the presence of too much of Taq Polymerase is inhibitory to the amplification reaction. A significant difference in the band intensity was observed when 2.5 units of Taq DNA polymerase was used as compared to the 15 and 25 units of Taq DNA polymerase. A standard amount of Taq DNA polymerase, which is 2.5 units was found to be the optimum amount to ensure the most optimal asymmetric PCR amplification.

Comparison of the optimization in this study to that of the other studies performed-What have we learned

Optimization of the asymmetric PCR was performed first by our group Citartan et al., 2012 followed by Tabarzad et al., 2014 and Heiat et al., 2017 [13-15]. The optimized parameters were tabulated as can be seen in Table 2. Collectively, none of the studies including the present study overlap which each other in the values of the optimized asymmetric PCR parameters, which implies the need to optimize for each different library prior to the start of any SELEX experiment. While all the libraries have different lengths, the sequence analysis between all the different libraries reveals no sequence similarity and as a consequence each library is expected to adopt a myriad of secondary structures that may be vary tremendously 
from each other. The large differences in the pattern of secondary structures between each library may affect the amplification efficiency of the asymmetric PCR to different degrees. Premising on this, overlapping values of the parameters across all these studies can never be expected, which corroborates the importance of optimizing the asymmetric PCR amplification for each different library before embarking on any SELEX experiment to ensure an optimum yield of ssDNA from each SELEX cycle. Insert Table 2

Incorporation of the ssDNA generation method further improves the yield of SSDNA of the asymmetric PCR reaction

Asymmetric PCR amplification produces both SsDNA and dsDNA due to the biphasic amplification which consists of both the logarithmic and linear amplification. The logarithmic phase of asymmetric PCR accounts for the presence of dsDNA and we suppose that the remnant dsDNA can be converted to ssDNA to further improve the yield of the latter. In the present study, we have incorporated asymmetric PCR assay with another strategy of ssDNA generation. In the first strategy, we have utilized lambda exonuclease digestion, which is based on the enzyme known as lambda exonuclease that selectively excise phosphorylated strand of a dsDNA, leaving another strand in the form of ssDNA. The undigested strand, remaining as ssDNA combines with the existing ssDNA in the asymmetric PCR reaction, increasing the total amount of ssDNA. Prior to the lambda exonuclease digestion assay, a time course analysis was performed from $15 \mathrm{~min}$ to $60 \mathrm{~min}$ to find out the optimum digestion time without the issue of over-digestion of ssDNA. We discovered that $15 \mathrm{~min}$ of digestion is enough to remove the dsDNA, while extending the digestion time up to 60 min resulted in no significant difference in the dsDNA 
intensity (Figure 6a and Figure 6b). Having determined the time of digestion, we carried out an asymmetric PCR reaction and subjected the reaction to the lambda exonuclease digestion. As can be observed from Figure 7a and Figure $7 \mathbf{b}$, a dramatic increase in the ssDNA band intensity suggests that the incorporation of the lambda exonuclease digestion step can further increase the yield of ssDNA of the asymmetric PCR reaction. Similar enhancement of the ssDNA band intensity can be seen as from Figure 7c and Figure 7d, which also supports the potency of biotinstreptavidin-mediated separation in augmenting the yield of ssDNA.

Cost and the amount of SsDNA recovered favoured A-PCR-lambda exonuclease digestion as the ideal method for generation of ssDNA

All the resulting asymmetric PCR, asymmetric PCR-lambda exonuclease and asymmetric PCR-biotin-streptavidin-mediated separation reactions were subjected to purification using gel extraction kit to selectively purify the ssDNA. As a whole, compared to the yield reported by Svobodova et al., 2012 [17], we have obtained a much higher yield of ssDNA following the purification of the asymmetric PCR, asymmetric PCR-lambda exonuclease digestion and asymmetric PCR-biotinstreptavidin-mediated separation product (Table 2). The most possible reason for the higher yield is the much extensive optimization of the asymmetric PCR reactions, which have bolstered the yield of ssDNA prior to the additional SsDNA purification.

Similar to the results from Svobodova's group, our findings showed that the incorporation of ssDNA step such as lambda exonuclease digestion (700 $\pm 11.3 \mathrm{nM})$ and biotin-streptavidin separation $(820 \pm 19.2 \mathrm{nM})$ significantly improved the yield of ssDNA compared to asymmetric PCR alone (450 $\pm 10.2 \mathrm{nM})$. As an ideal ssDNAgenerating techniques, both the A-PCR- lambda exonuclease digestion and A-PCR- 
biotin-streptavidin separation are able to generate a high amount of ssDNA at an affordable cost. A high amount of ssDNA generated is able to minimize the chance of losing potential binders of a SELEX experiment during the selective purification of ssDNA. Compared to A-PCR, the A-PCR-lambda exonuclease digestion appears to be more prominent due to its ability to generate the amount of ssDNA approximately 2-fold higher than that of A-PCR alone. This can be achieved at a similar cost albeit with a slightly longer duration. Compared to the A-PCR-lambda exonuclease digestion, A-PCR-biotin-streptavidin seems to be able to produce a higher yield of ssDNA. However, in terms of cost, A-PCR-lambda exonuclease digestion is preferred over A-PCR-biotin-streptavidin due to the much lower cost. However, in terms of time, both these techniques require similar duration. The most prominent finding from our study is the significance of developing an optimization pipeline for the asymmetric PCR reaction prior to the selective purification, which could augment the yield of ssDNA.

\section{Conclusion}

We have successfully developed an optimization pipeline of the asymmetric PCR reaction, demonstrating the step-by-step optimization of the parameters that could improve the yield of the ssDNA. An additional ssDNA generation step was also included in the pipeline to further augment the yield of ssDNA. We have successfully obtained a value of up to $700 \pm 11.3$ and $820 \pm 19.2 \mathrm{nM}$ using two different additional ssDNA generation strategy. It is strongly recommended to develop a separate optimization pipeline of asymmetric PCR for each different randomized ssDNA library before initiating any SELEX experiment. 


\section{Acknowledgement}

We acknowledge the Ministry of Higher Education, Malaysia for Skim Latihan Akademik Bumiputra (SLAB). We declare no conflict of interest in regards to this manuscript.

\section{Funding}

Citartan $\mathrm{M}$ and Tang $\mathrm{TH}$ were supported by USM Research University Grant (1001.CIPPT.8011095).

\section{References:}

1. Hermann, T. and D.J. Patel, Adaptive recognition by nucleic acid aptamers. Science, 2000. 287(5454): p. 820-5.

2. Nomura, Y., et al., Conformational plasticity of RNA for target recognition as revealed by the 2.15 A crystal structure of a human IgG-aptamer complex. Nucleic acids research, 2010. 38(21): p. 7822-7829.

3. Piganeau, N. and R. Schroeder, Aptamer structures: a preview into regulatory pathways? Chem Biol, 2003. 10(2): p. 103-4.

4. Ellington, A.D. and J.W. Szostak, In vitro selection of RNA molecules that bind specific ligands. Nature, 1990. 346(6287): p. 818-22.

5. Tuerk, C. and L. Gold, Systematic evolution of ligands by exponential enrichment: RNA ligands to bacteriophage T4 DNA polymerase. Science, 1990. 249(4968): p. 505-10. 
6. McKeague, M. and M.C. DeRosa, Challenges and Opportunities for Small Molecule Aptamer Development. Journal of Nucleic Acids, 2012. 2012: p. 748913.

7. Elskens, J.P., J.M. Elskens, and A. Madder, Chemical Modification of Aptamers for Increased Binding Affinity in Diagnostic Applications: Current Status and Future Prospects. 2020. 21(12).

8. Odeh, F., et al., Aptamers Chemistry: Chemical Modifications and Conjugation Strategies. Molecules, 2019. 25(1).

9. Hao, M., J. Qiao, and H. Qi, Current and Emerging Methods for the Synthesis of Single-Stranded DNA. Genes (Basel), 2020. 11(2).

10. Mosing, R.K. and M.T. Bowser, Isolating Aptamers Using Capillary Electrophoresis-SELEX (CE-SELEX), in Nucleic Acid and Peptide Aptamers: Methods and Protocols, G. Mayer, Editor. 2009, Humana Press: Totowa, NJ. p. 33-43.

11. Avci-Adali, M., et al., Upgrading SELEX technology by using lambda exonuclease digestion for single-stranded DNA generation. Molecules (Basel, Switzerland), 2009. 15(1): p. 1-11.

12. Citartan, M., et al., Conditions optimized for the preparation of single-stranded DNA (ssDNA) employing lambda exonuclease digestion in generating DNA aptamer. World Journal of Microbiology and Biotechnology, 2011. 27(5): p. 1167-1173.

13. Citartan, M., et al., Asymmetric PCR for good quality ssDNA generation towards DNA aptamer production. Songklanakarin Journal of Science and Technology, 2012. 34: p. 125-131. 
14. Tabarzad, M., et al., Challenges to design and develop of DNA aptamers for protein targets. I. Optimization of asymmetric PCR for generation of a single stranded DNA library. Iranian journal of pharmaceutical research : IJPR, 2014. 13(Suppl): p. 133-141.

15. Heiat, M., et al., Essential strategies to optimize asymmetric PCR conditions as a reliable method to generate large amount of ssDNA aptamers. Biotechnol Appl Biochem, 2017. 64(4): p. 541-548.

16. Tolle, F., et al., By-product formation in repetitive PCR amplification of DNA libraries during SELEX. PLoS One, 2014. 9(12): p. e114693.

17. Svobodová, M., et al., Comparison of different methods for generation of single-stranded DNA for SELEX processes. Anal Bioanal Chem, 2012. 404(3): p. 835-42. 


\section{Figure legends:}

\section{Table 1}

Yield of ssDNA generated by our method

\section{Table 2}

Comparison of the optimization of the parameters in the asymmetric PCR

\section{Figure 1}

Effect of number of PCR cycles from 1 cycle to 6 cycles on symmetric PCR amplification. (a) $4 \%$ agarose gel electrophoresis of symmetric PCR products from different number of PCR cycles. Lane 1: 25 b.p. DNA ladder, Lane 2: 1 cycle, Lane 3: 2 cycles, Lane 4: 3 cycles, Lane 5: 4 cycles, Lane 6: 5 cycles and Lane 7: 6 cycles. (b) Bar graph of band intensities of dsDNA from different number of PCR cycles as estimated by Image J analysis. Error bars represent standard deviation of 3 replicates. $P<0.05$ was considered as statistically significant while ${ }^{* * *}=P<0.0001$ and ns= not significant. (c) Bar graph of band intensities of smear from different number of PCR cycles as estimated by ImageJ analysis. Error bars represent standard deviation of 3 replicates. $P<0.05$ was considered as statistically significant while $^{* * *}=\mathrm{P}<0.001,{ }^{* * *}=\mathrm{P}<0.0001$ and $\mathrm{ns}=$ not significant.

\section{Figure 2}

Effect of amount of PCR primers from $10 \mathrm{pmol}$ to $100 \mathrm{pmol}$ on symmetric PCR amplification. (a) $4 \%$ agarose gel electrophoresis of symmetric PCR products from different amounts of PCR primers. Lane 1: 25 b.p. DNA ladder, Lane 2: 10 pmol, Lane 3: 20 pmol, Lane 4: $30 \mathrm{pmol}$, Lane 5: $40 \mathrm{pmol}$, Lane 6: $50 \mathrm{pmol}$, Lane 7: 60 pmol, Lane 8: 70 pmol, Lane 9: 80 pmol, Lane 10: 90 pmol and Lane 11: 100 pmol. 
(b) Bar graph of band intensities of dsDNA from different amounts of primers as estimated by ImageJ analysis. Error bars represent standard deviation of 3 replicates. $P<0.05$ was considered as statistically significant while ${ }^{* *}=P<0.01$, $* * * *=P<0.0001$ and ns= not significant.

\section{Figure 3}

Effects of annealing temperatures $\left(55.0^{\circ} \mathrm{C}, 55.7^{\circ} \mathrm{C}, 56.9^{\circ} \mathrm{C}, 58.7^{\circ} \mathrm{C}, 61.1^{\circ} \mathrm{C}, 63.0\right.$ ${ }^{\circ} \mathrm{C}, 64.2{ }^{\circ} \mathrm{C}$ and $\left.65.0{ }^{\circ} \mathrm{C}\right)$ and primer ratios $(20: 0,20: 0.5,20: 1,20: 2,50: 1$ and 100:1) on asymmetric PCR amplification. (a) 4\% agarose gel electrophoresis of asymmetric PCR products from different annealing temperatures. Lane 1: 25 b.p. DNA ladder, Lane 2: $55^{\circ} \mathrm{C}$, Lane 3: $55.7^{\circ} \mathrm{C}$, Lane $4: 56.9{ }^{\circ} \mathrm{C}$, Lane 5: $58.7^{\circ} \mathrm{C}$, Lane 6: $61.1^{\circ} \mathrm{C}$, Lane 7: $63.0{ }^{\circ} \mathrm{C}$, Lane 8: $64.2{ }^{\circ} \mathrm{C}$ and Lane 9: $65.0{ }^{\circ} \mathrm{C}$. (b) Bar graph of band intensities of ssDNA from different annealing temperatures as estimated by ImageJ analysis. Error bars represent standard deviation of 3 replicates. $\mathrm{P}<0.05$ was considered as statistically significant while ${ }^{*}=\mathrm{P}<0.05,{ }^{* *}=\mathrm{P}<0.01$ and ${ }^{* * * *}=\mathrm{P}<$ 0.0001. (c) $4 \%$ agarose gel electrophoresis of asymmetric PCR products from different primer ratios as estimated by ImageJ analysis. (d) Bar graph of band intensities of ssDNA from different primer ratios as estimated by ImageJ analysis. Error bars represent standard deviation of 3 replicates. $\mathrm{P}<0.05$ was considered as statistically significant while ${ }^{* * *}=P<0.0001$ and ns= not significant.

\section{Figure 4}

Effects of amounts of templates $(0.2 \mathrm{ng} / \mu \mathrm{L}, 0.4 \mathrm{ng} / \mu \mathrm{L}, 0.8 \mathrm{ng} / \mu \mathrm{L}$ and $1.6 \mathrm{ng} / \mu \mathrm{L})$ and number of PCR cycles (10 cycles, 20 cycles and 30 cycles) on asymmetric PCR amplification. (a) $4 \%$ agarose gel electrophoresis of the asymmetric PCR products from different amounts of templates. Lane 1: 25 b.p. DNA ladder, Lane 2: $0.2 \mathrm{ng} / \mu \mathrm{L}$, 
Lane 3: $0.4 \mathrm{ng} / \mu \mathrm{L}$, Lane 4: $0.8 \mathrm{ng} / \mu \mathrm{L}$ and Lane 5: $1.6 \mathrm{ng} / \mu \mathrm{L}$. (b) Bar graph of band intensities of ssDNA from different amounts of templates as estimated by ImageJ analysis. Error bars represent standard deviation of 3 replicates. $\mathrm{P}<0.05$ was considered as statistically significant while ${ }^{* * * *}=P<0.0001$. (c) $4 \%$ agarose gel electrophoresis of the asymmetric PCR products from different number of PCR cycles. Lane 1: 25 b.p. DNA ladder, Lane 2: 10 cycles, Lane 3: 20 cycles and Lane 4: 30 cycles. (d) Bar graph of band intensities of ssDNA from different number of PCR cycles as estimated by ImageJ analysis. Error bars represent standard deviation of 3 replicates. $P<0.05$ was considered as statistically significant while ${ }^{* * *}=\mathrm{P}<0.001$

\section{Figure 5}

Effects of dNTPs/MgCl $2(0.2 \mathrm{mM} / 1.5 \mathrm{mM}, 0.4 \mathrm{mM} / 2.0 \mathrm{mM}, 0.6 \mathrm{mM} / 2.5 \mathrm{mM}, 0.8$ $\mathrm{mM} / 3.0 \mathrm{mM}$ and $1.0 \mathrm{mM} / 3.5 \mathrm{mM})$ and amount of Taq DNA polymerase $(2.5 \mathrm{U}, 5.0 \mathrm{U}$, $10.0 \mathrm{U}, 15.0 \mathrm{U}$ and $20.0 \mathrm{U}$ ) on asymmetric PCR amplification. (a) 4\% agarose gel electrophoresis of the asymmetric PCR products from different concentrations of dNTPs/MgCl . Lane 1: 25 b.p. DNA ladder, Lane 2: $0.2 \mathrm{mM} / 1.5 \mathrm{mM}$, Lane 3: 0.4 $\mathrm{mM} / 2.0 \mathrm{mM}$, Lane 4: $0.6 \mathrm{mM} / 2.5 \mathrm{mM}$, Lane 5: $0.8 \mathrm{mM} / 3.0 \mathrm{mM}$ and Lane 6: 1.0 $\mathrm{mM} / 3.5 \mathrm{mM}$. (b) Bar graph of band intensities of ssDNA from different concentrations dNTPs/MgCl 2 as estimated by ImageJ analysis. Error bars represent standard deviation of 3 replicates. $P<0.05$ was considered as statistically significant while ${ }^{* * * *}=P<0.0001$ and ns= not significant. (c) $4 \%$ agarose gel electrophoresis of the asymmetric PCR products from different amounts of Taq DNA polymerase. Lane 1: 25 b.p. DNA ladder, Lane 2: $2.5 \mathrm{U}$, Lane 3: $5.0 \mathrm{U}$, Lane 4: $10.0 \mathrm{U}$, Lane 5: $15.0 \mathrm{U}$ and Lane 6: 20.0 U. (d) Bar graph of band intensities of ssDNA from different 
amounts of Taq DNA polymerase as estimated by ImageJ analysis. Error bars represent standard deviation of 3 replicates. $P<0.05$ was considered as statistically significant while ${ }^{* *}=\mathrm{P}<0.01,{ }^{* * *}=\mathrm{P}<0.0001$ and ns= not significant.

\section{Figure 6}

Time course analysis of Lambda exonuclease digestion from $15 \mathrm{~min}$ to $60 \mathrm{~min}$. (a) $4 \%$ agarose gel electrophoresis of phosphorylated asymmetric PCR products from different digestion times. (b) Bar graph of band intensities of ssDNA from different digestion times as estimated by ImageJ analysis. Error bars represent standard deviation of 3 replicates. $P<0.05$ was considered as statistically significant while ${ }^{* * * *}=P<0.0001$ and $n s=$ not significant.

\section{Figure 7}

Effects of the incorporation of Lambda exonuclease digestion and biotin-streptavidin separation on the ssDNA intensity. (a) $4 \%$ agarose gel electrophoresis of asymmetric PCR products from A-PCR and A-PCR-lambda exonuclease digestion. Lane 1: 25 b.p. DNA ladder, Lane 2: A-PCR and Lane 3: A-PCR-lambda exonuclease digestion. (b) Bar graph of band intensities of ssDNA from A-PCR and A-PCR-lambda exonuclease digestion as estimated by ImageJ analysis. Error bars represent standard deviation of 3 replicates. $P<0.05$ was considered as statistically significant while ${ }^{* * *}=P<0.0001$. (c) $4 \%$ agarose gel electrophoresis of asymmetric PCR products from A-PCR and A-PCR-biotin-streptavidin separation. Lane 1: 25 b.p. DNA ladder, Lane 2: A-PCR and Lane 3: A-PCR-biotin-streptavidin separation. (d) Bar graph of band intensities of ssDNA from A-PCR and A-PCR-biotin-streptavidin separation as estimated by ImageJ analysis. Error bars represent standard deviation 
of 3 replicates. $P<0.05$ was considered as statistically significant while ${ }^{* *}=P<$ 0.001 . 
Figure 1

(a)

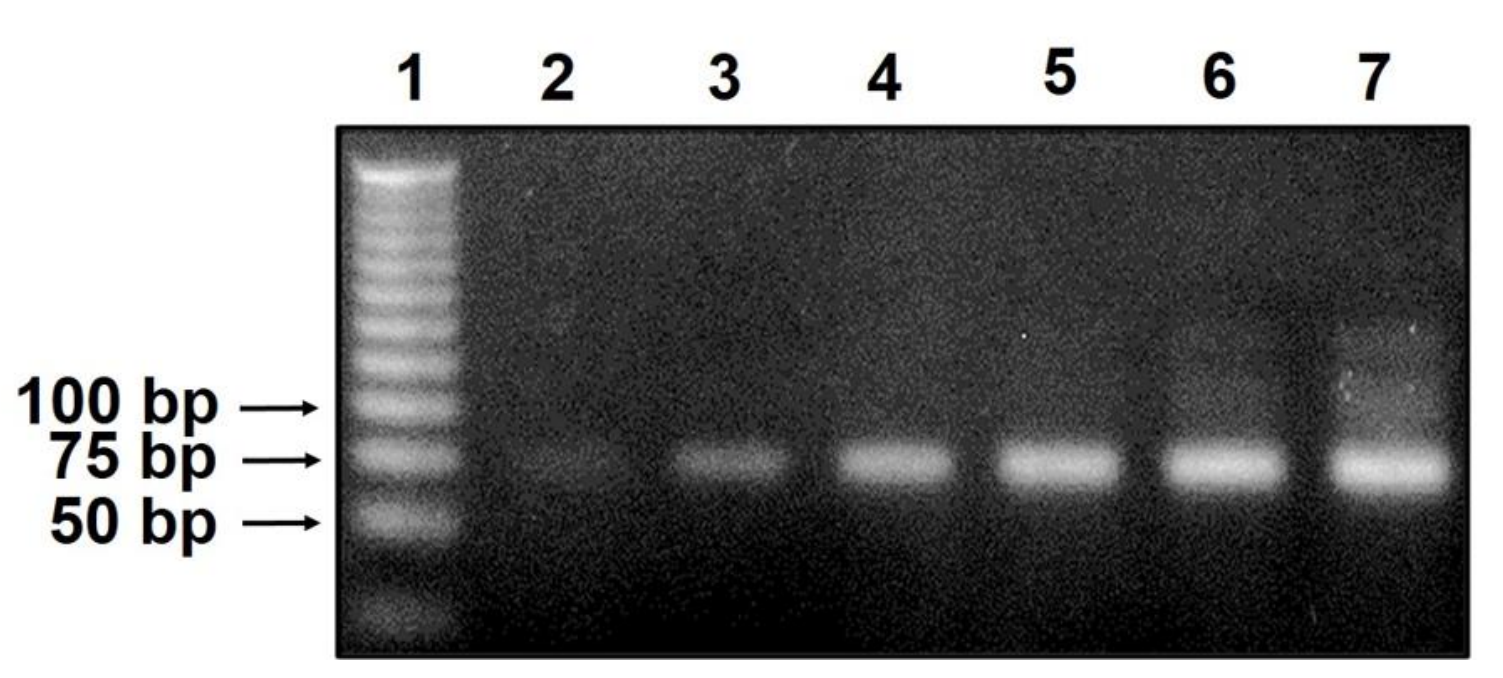

(c)

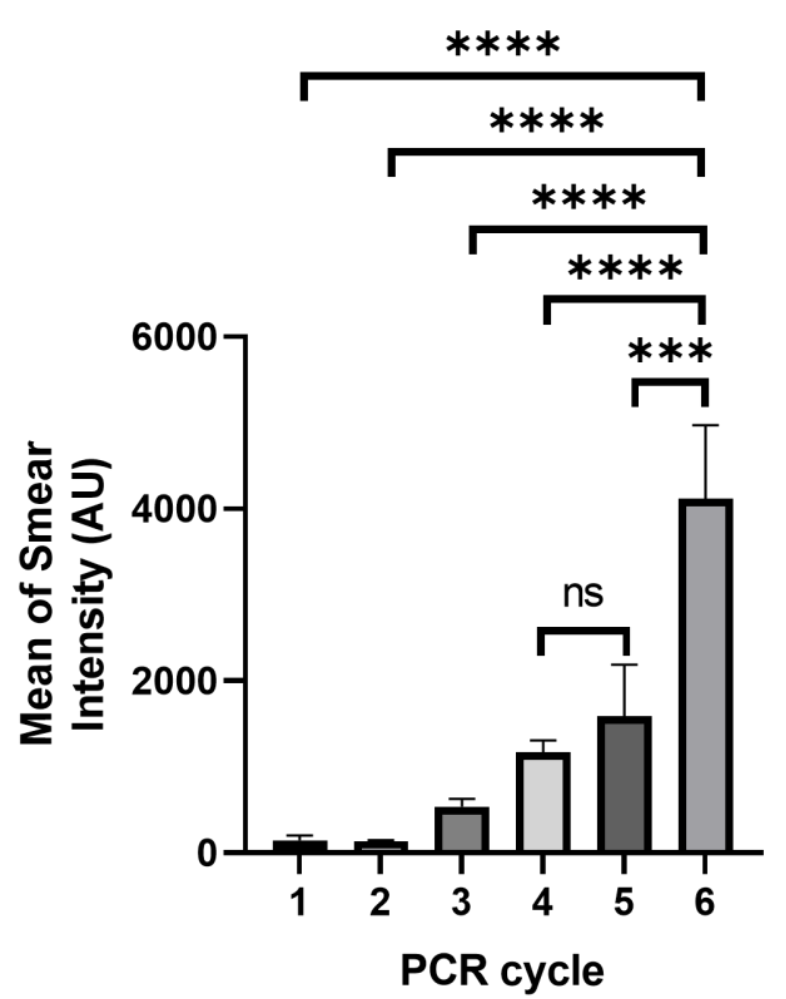

PCR cycle (b) 250007

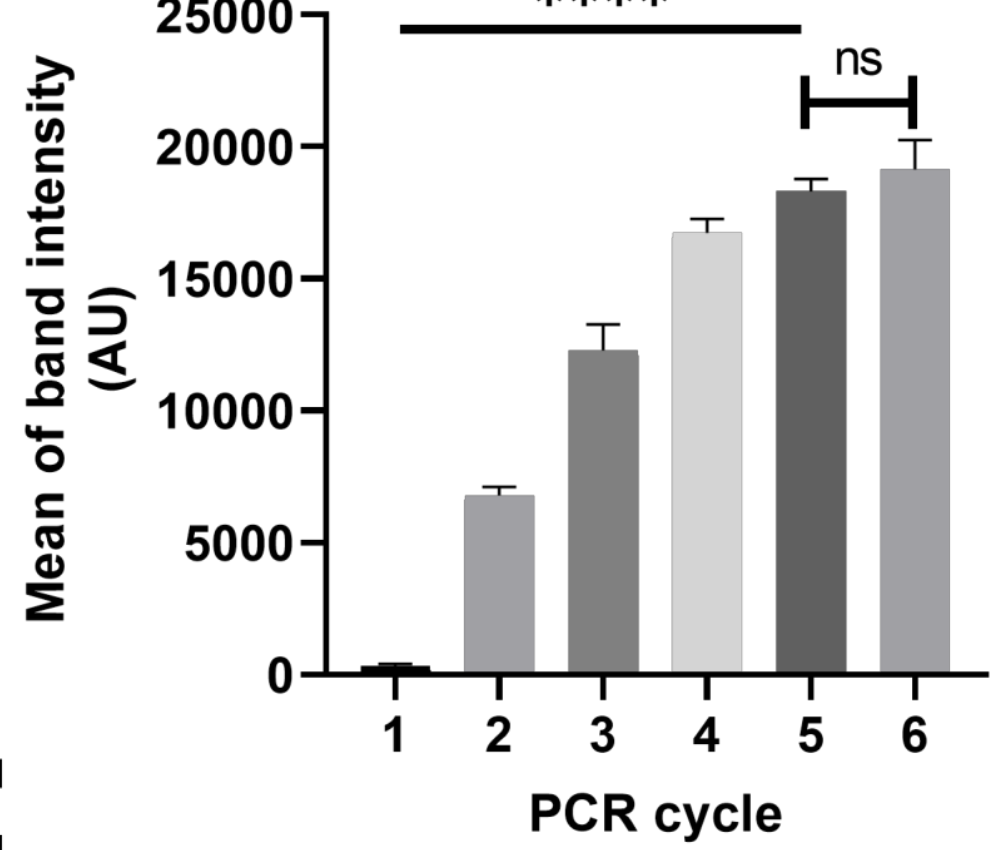




\section{Figure 2}

(a)

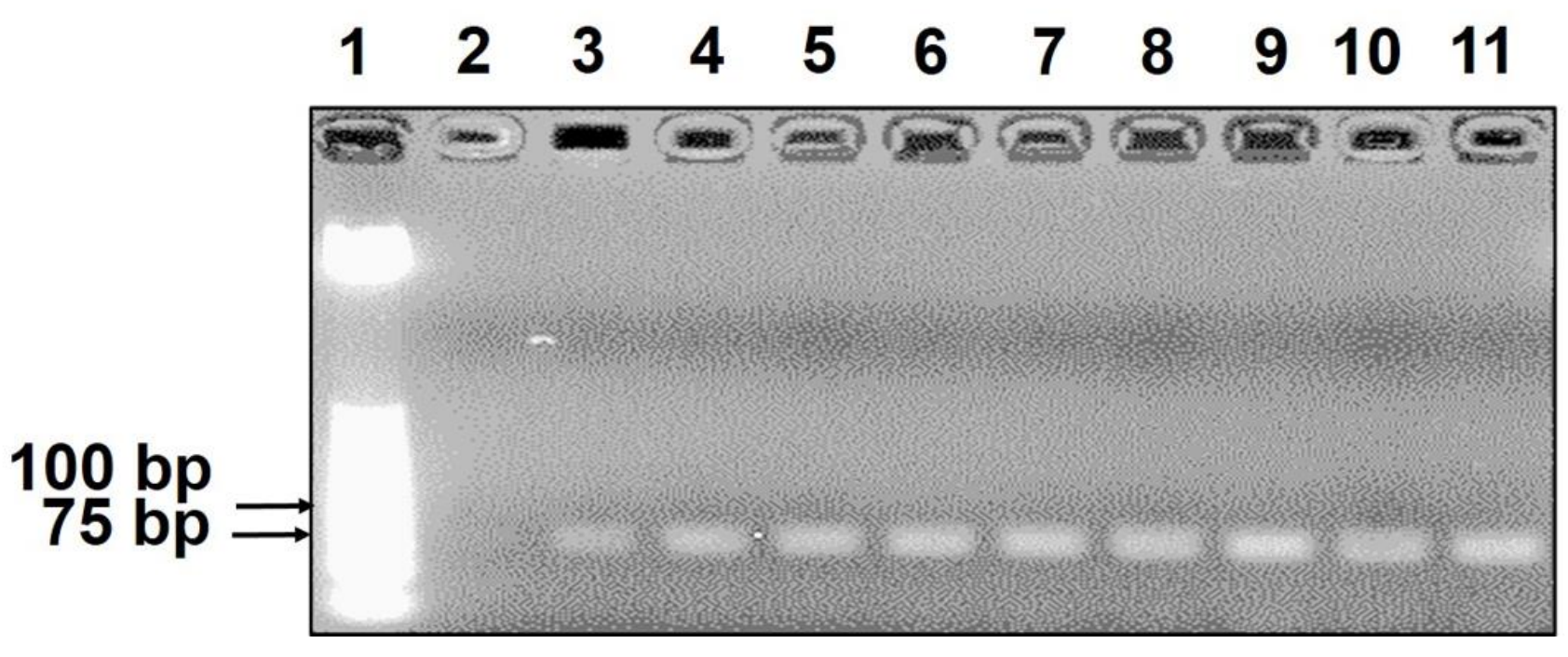

(b)

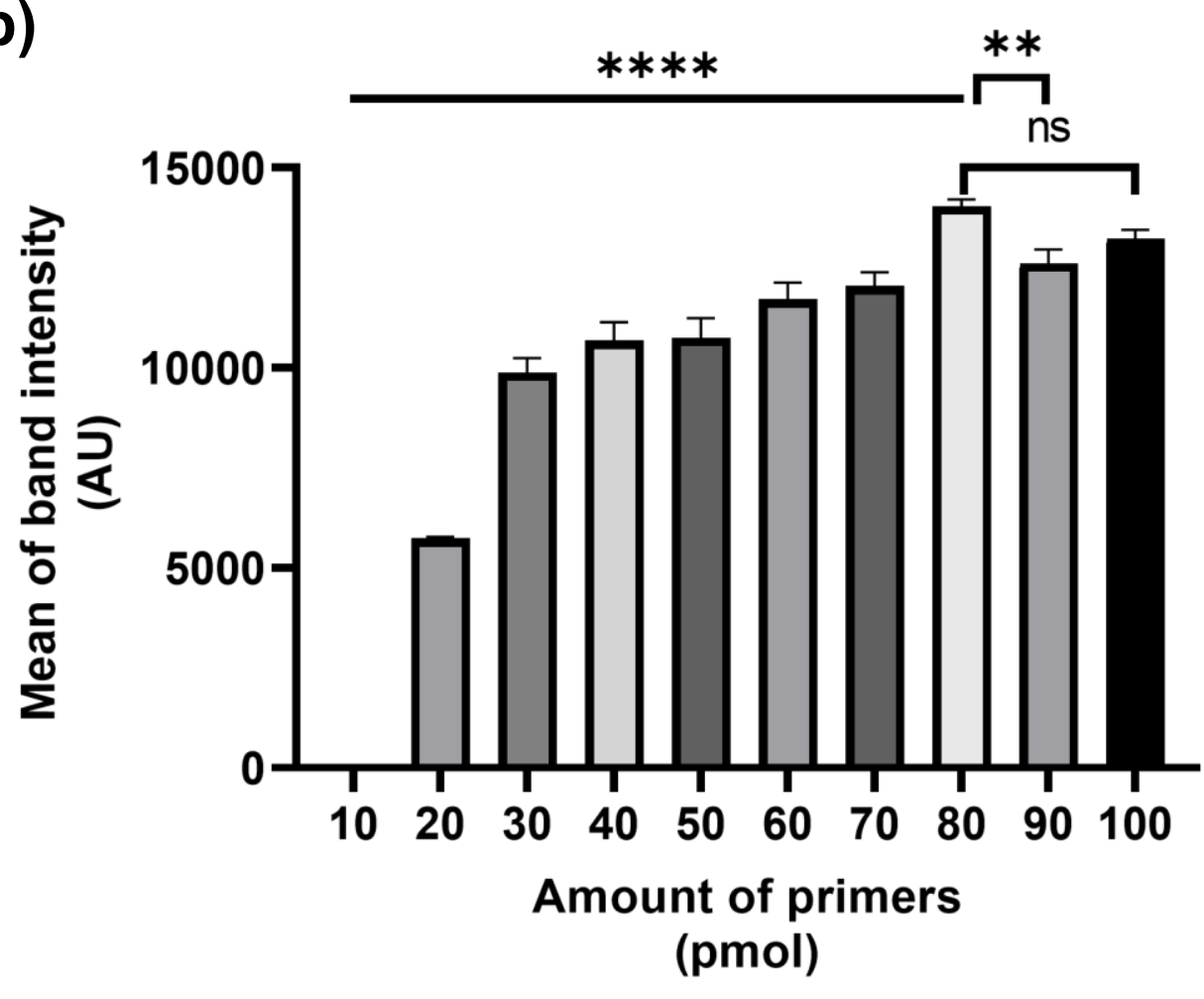


(a)

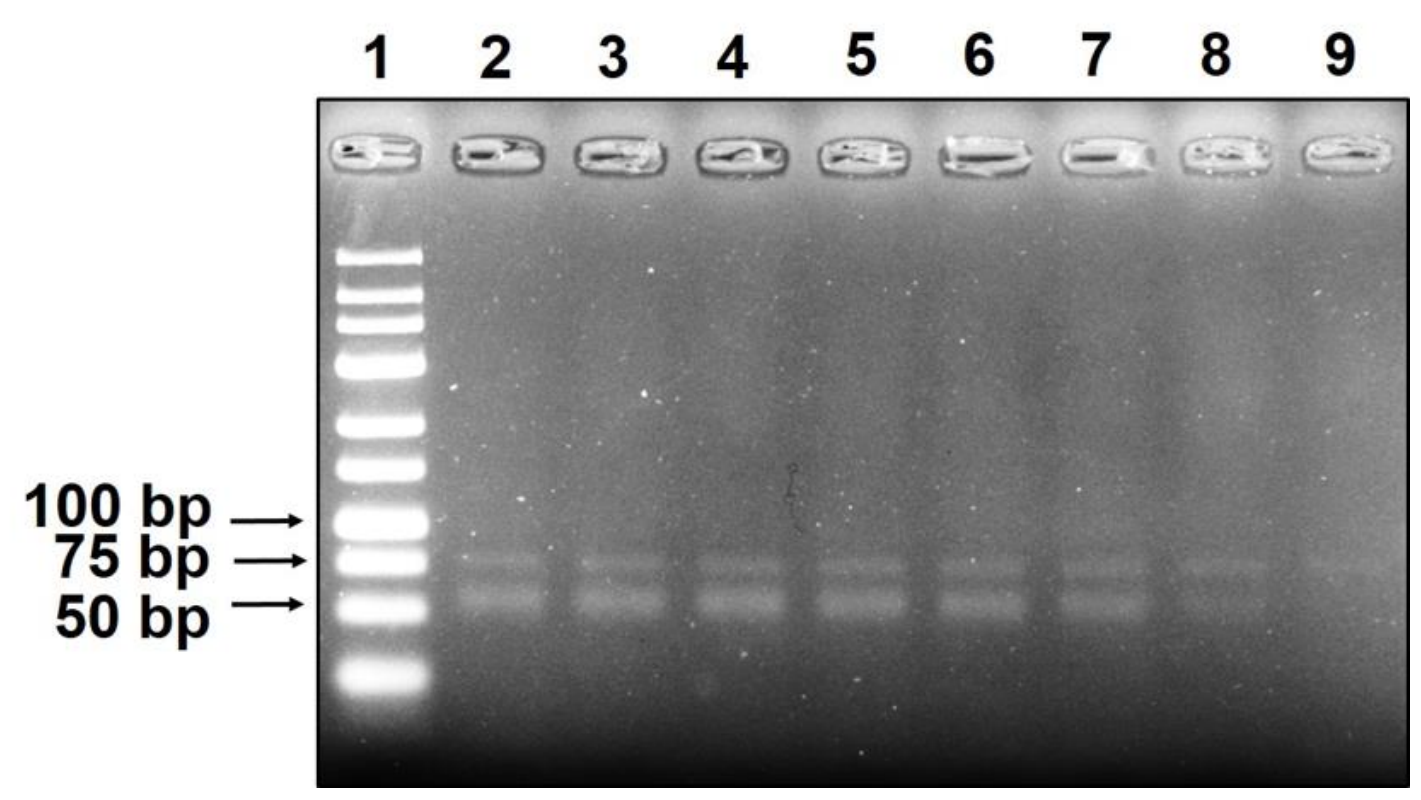

(c)

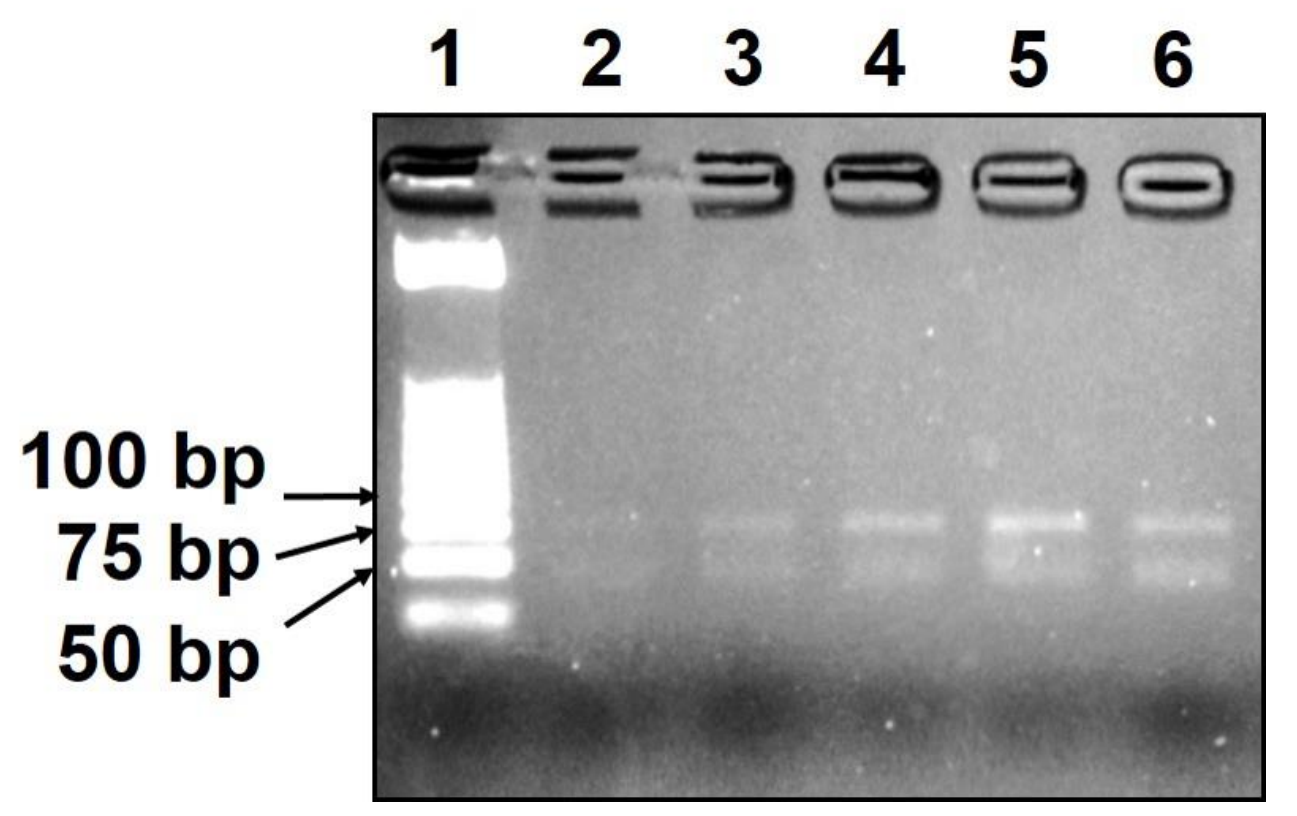

(b)

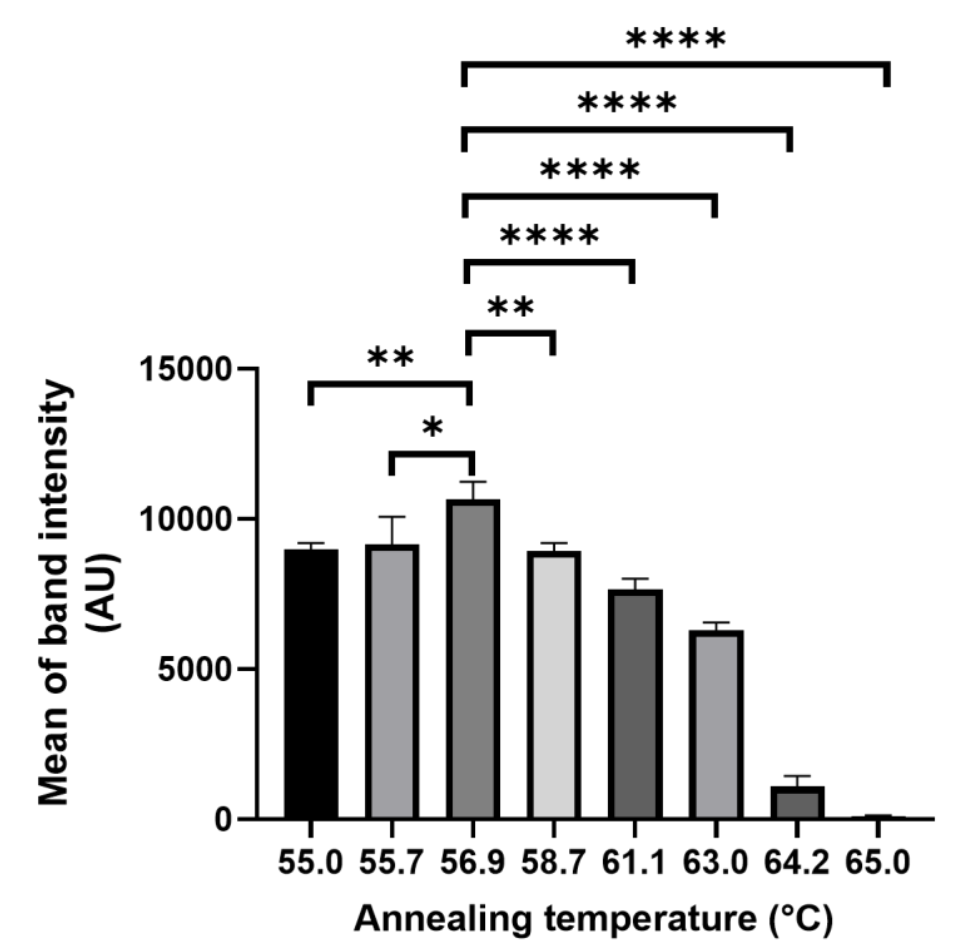

(d)

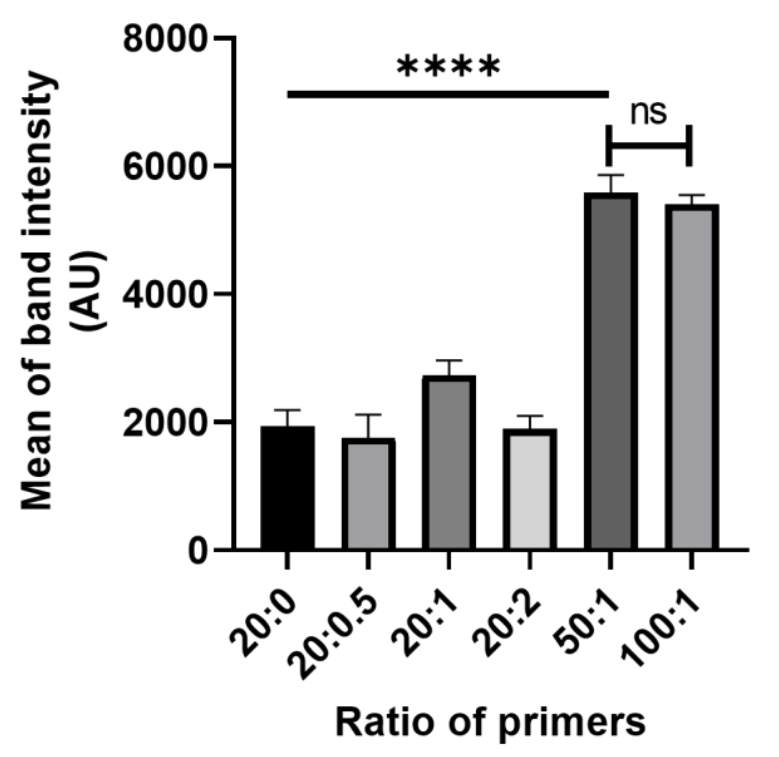


Figure 4

(a)

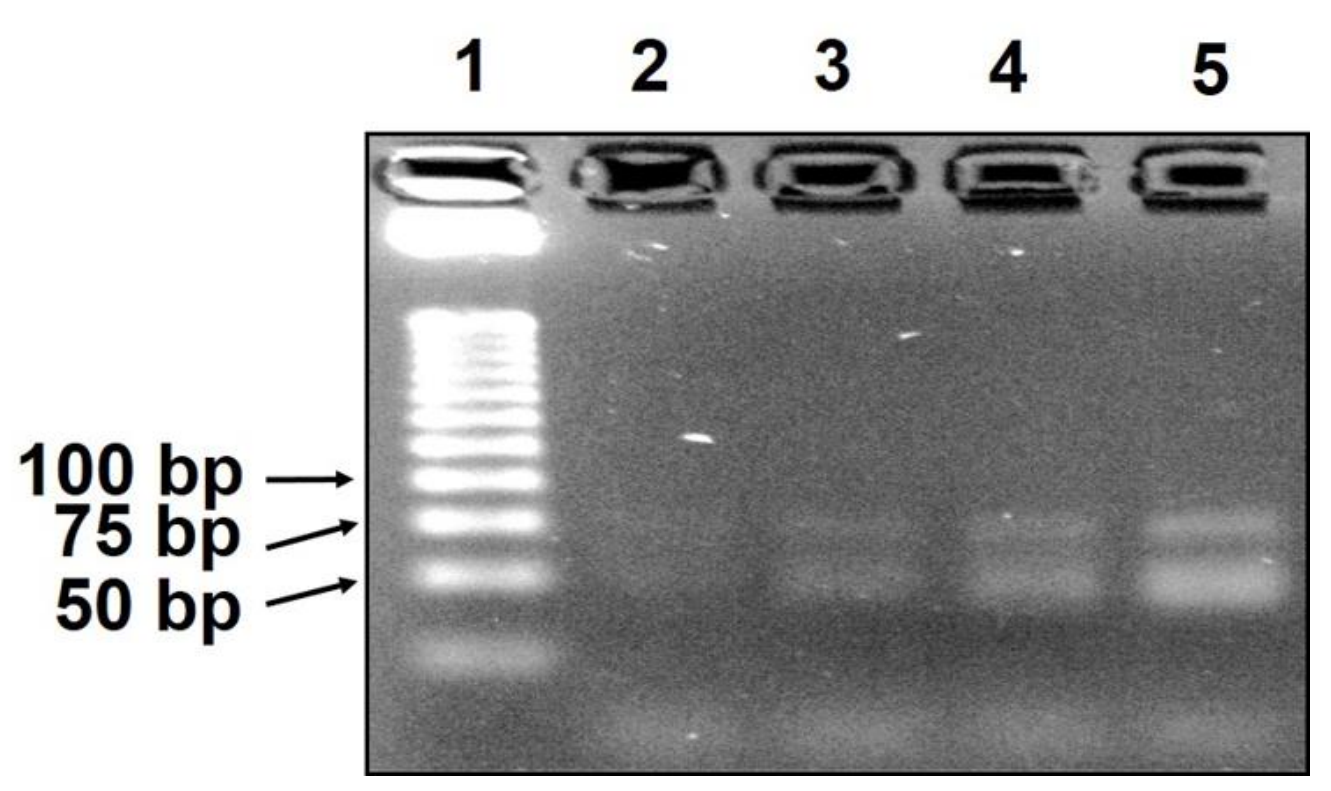

(c)

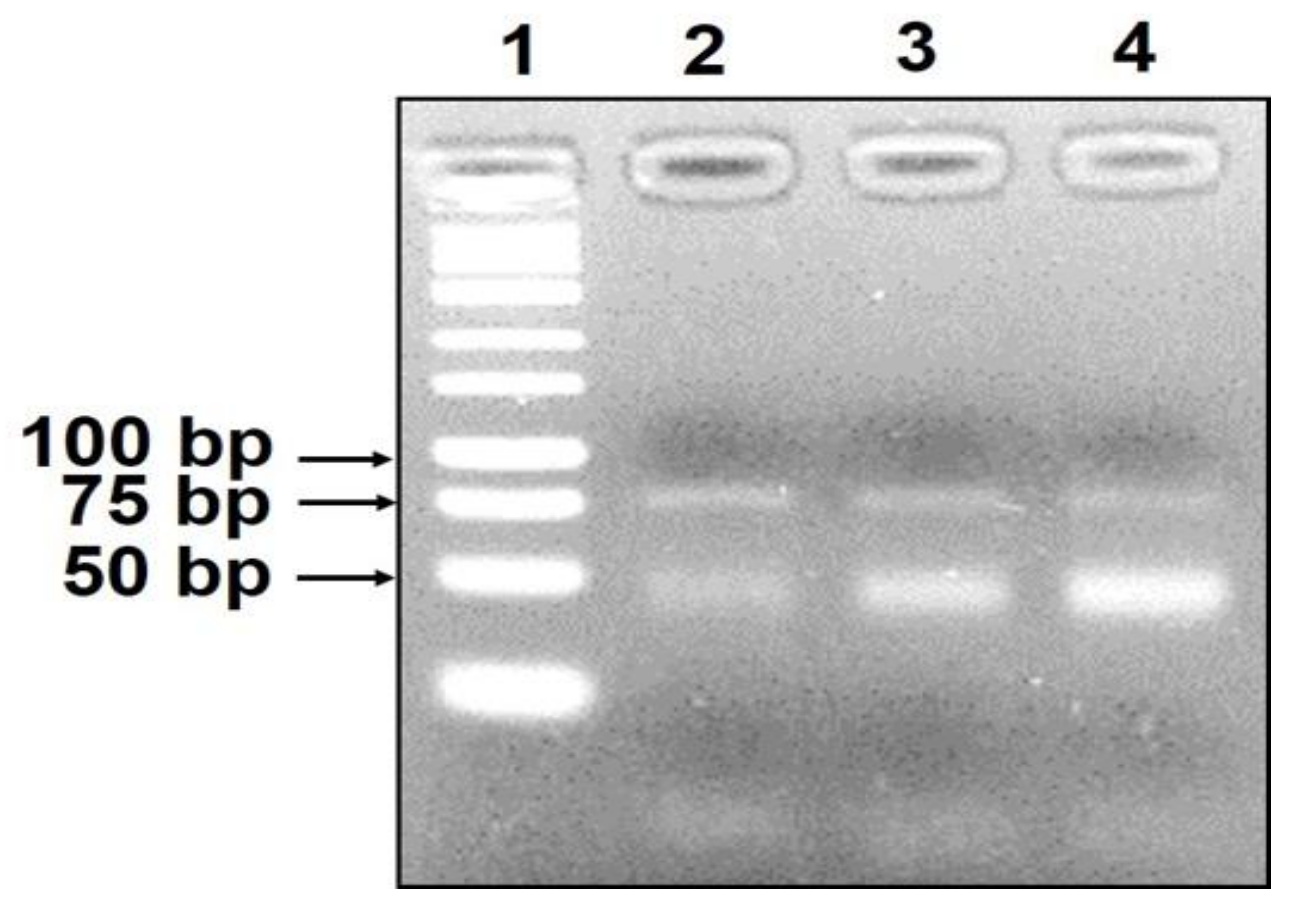

(b)

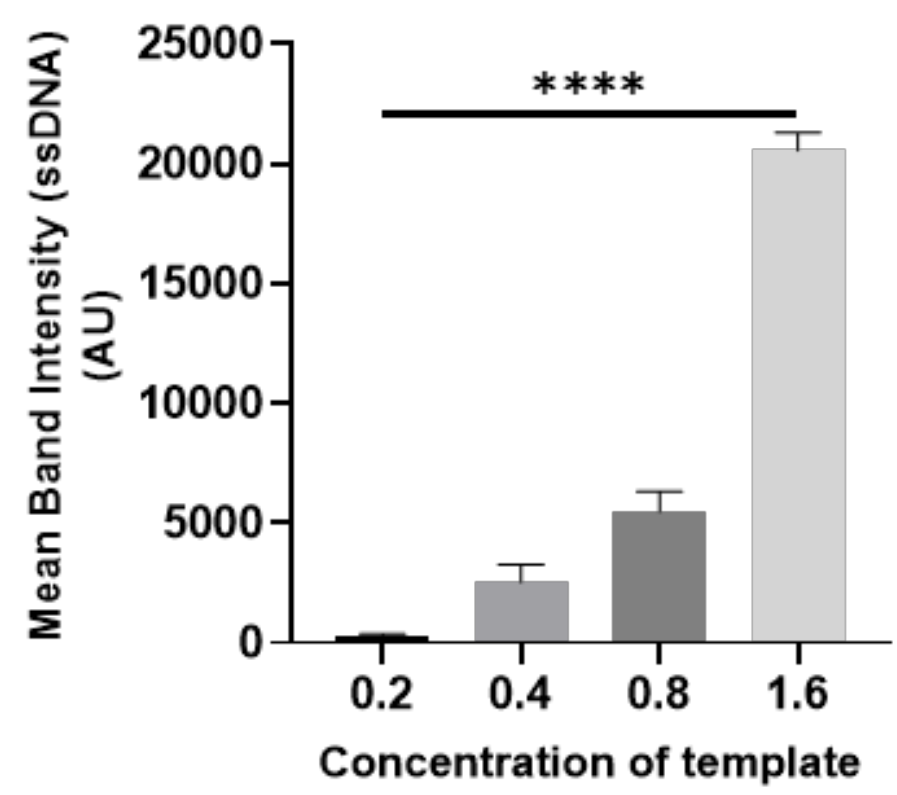

(d)

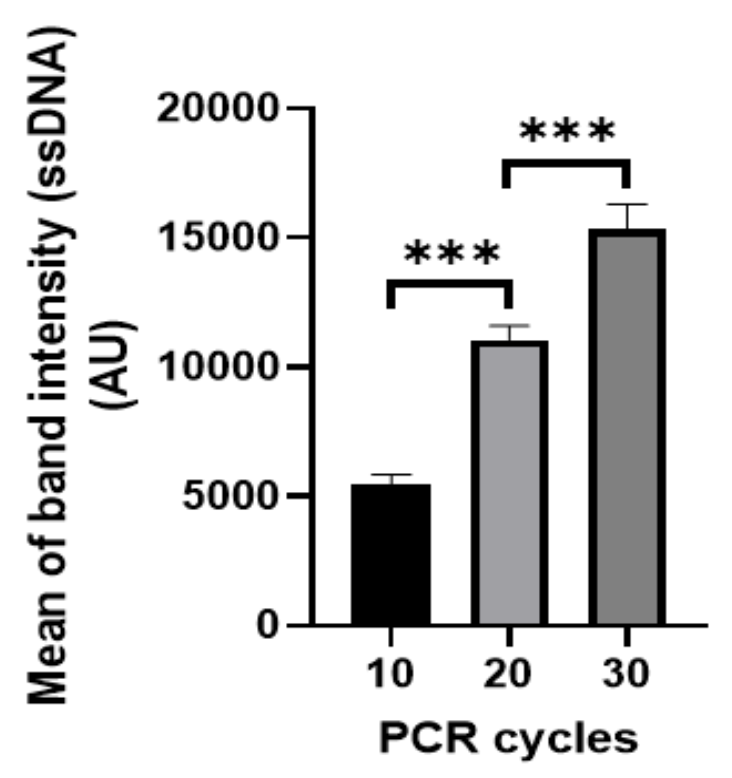




\section{Figure 6}

(a)

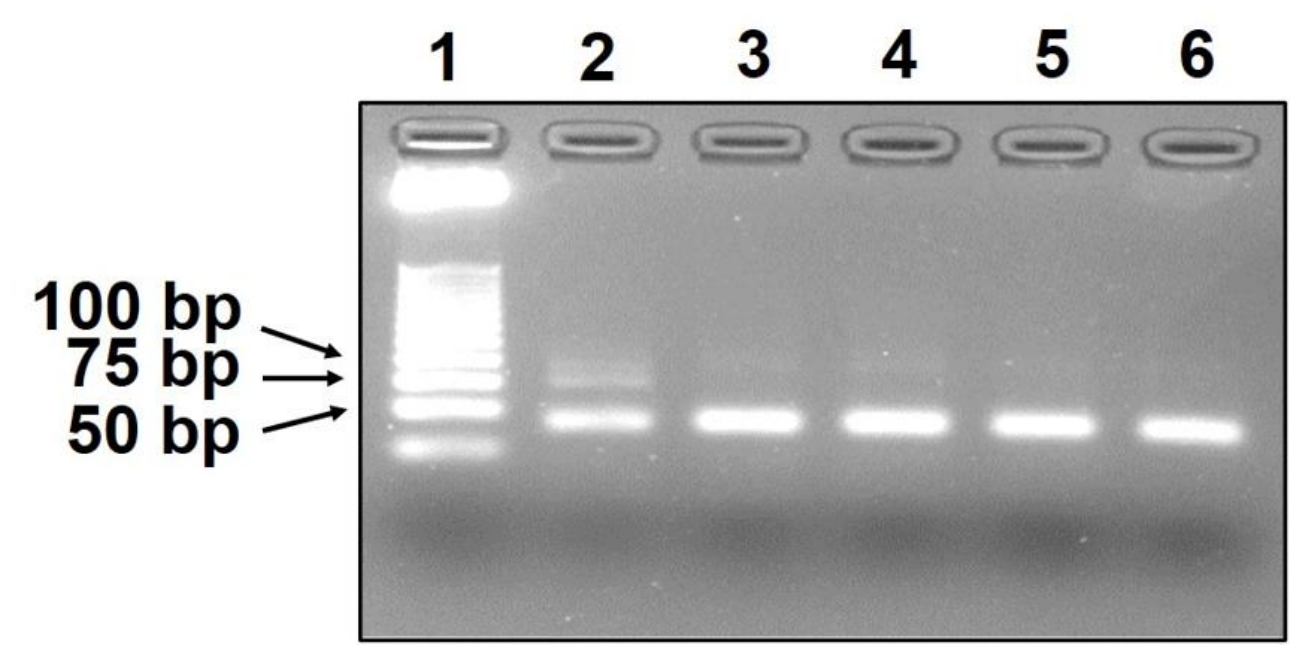

(b)

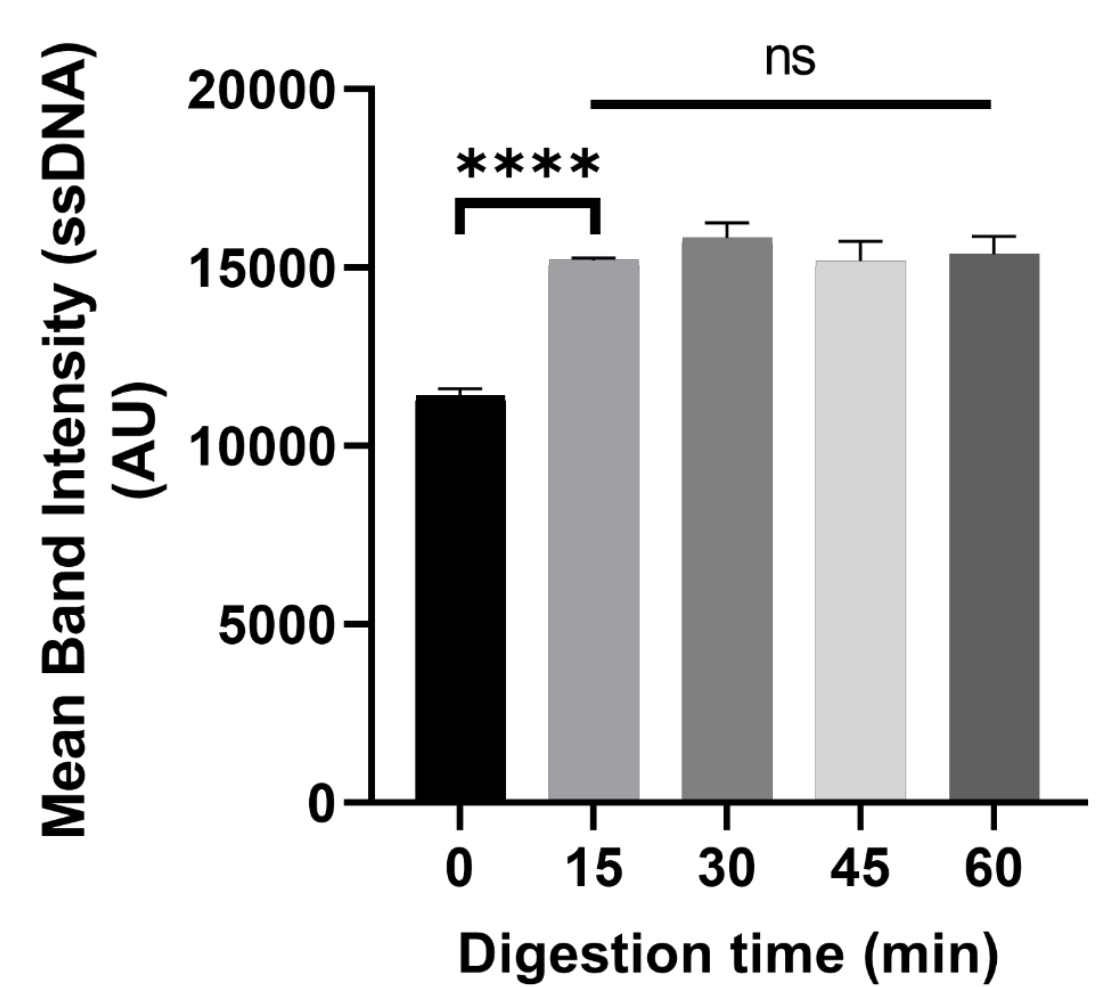


Figure 7

(a)

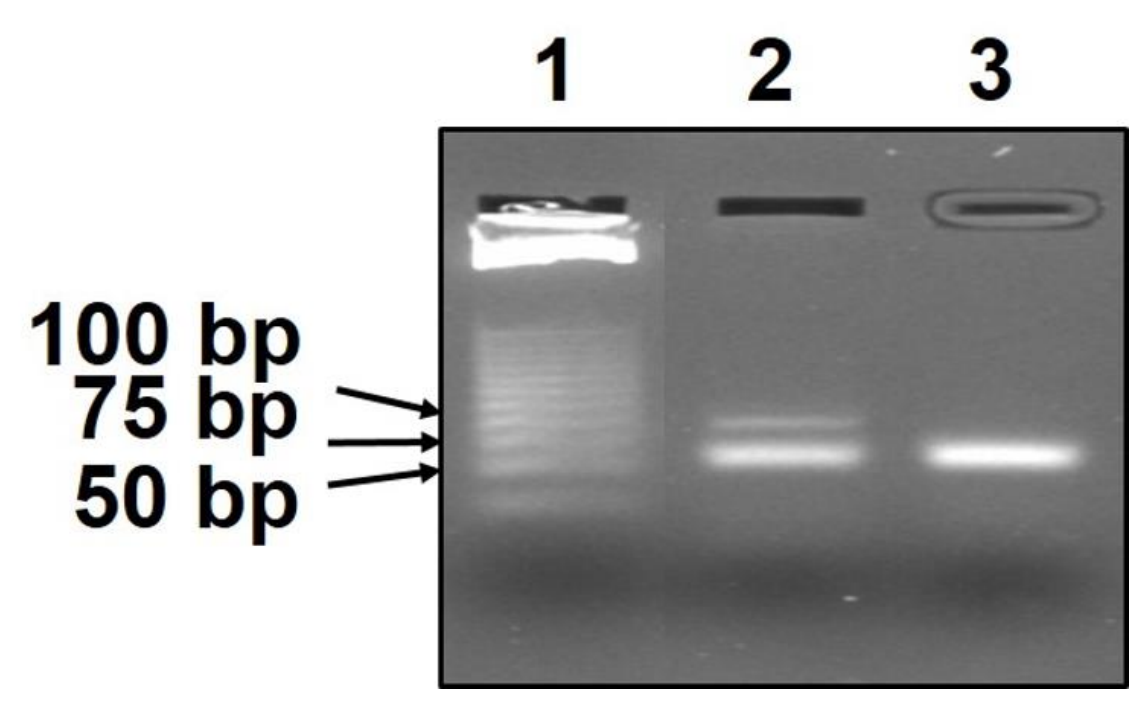

(c)

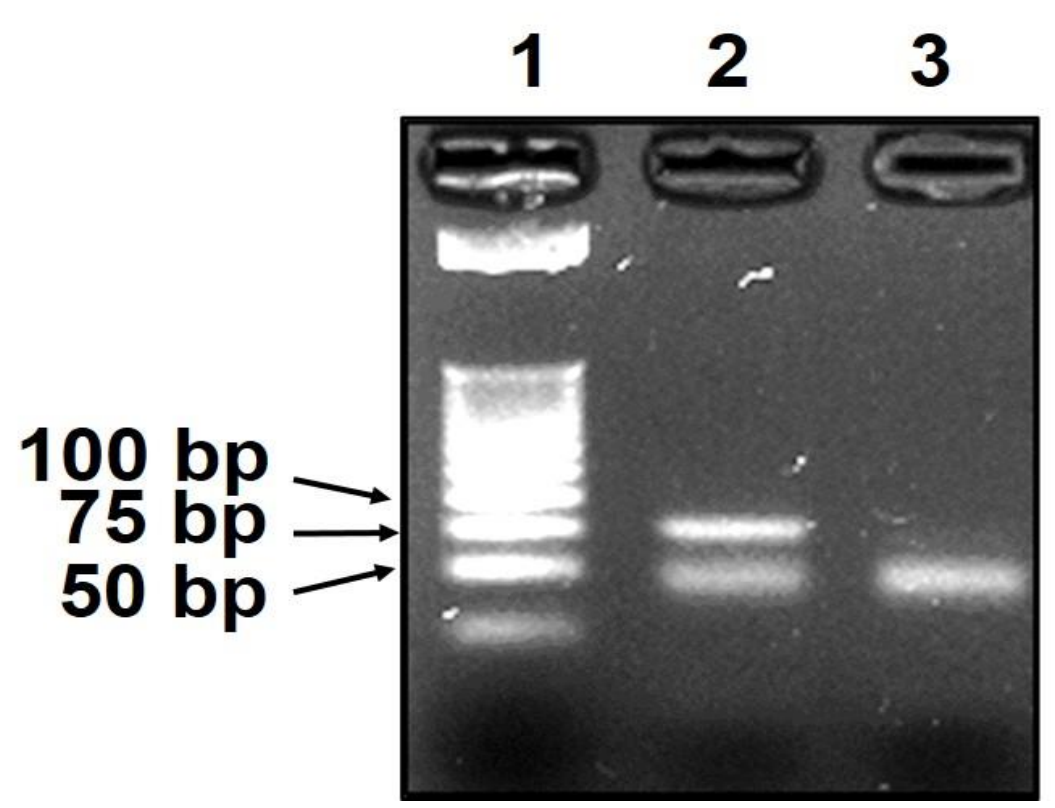

(b)

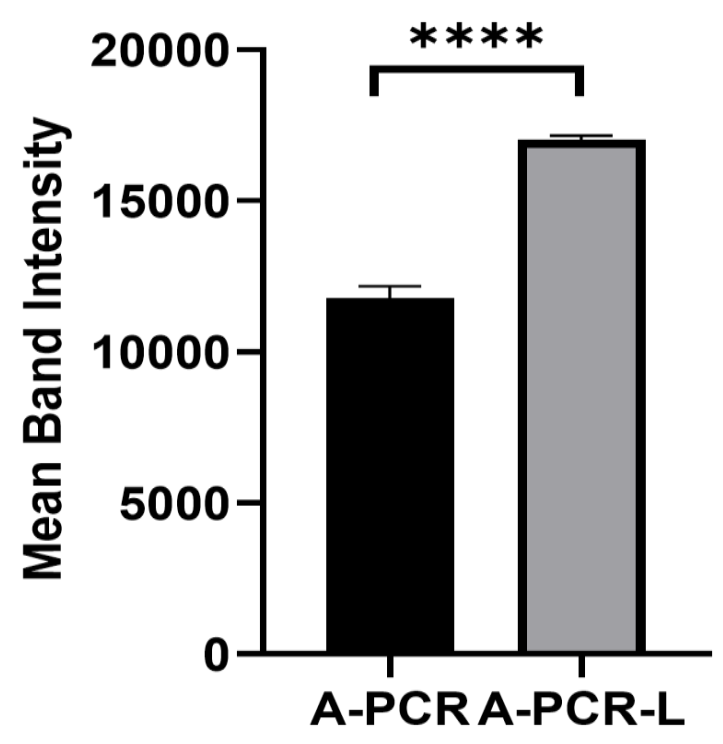

(d)

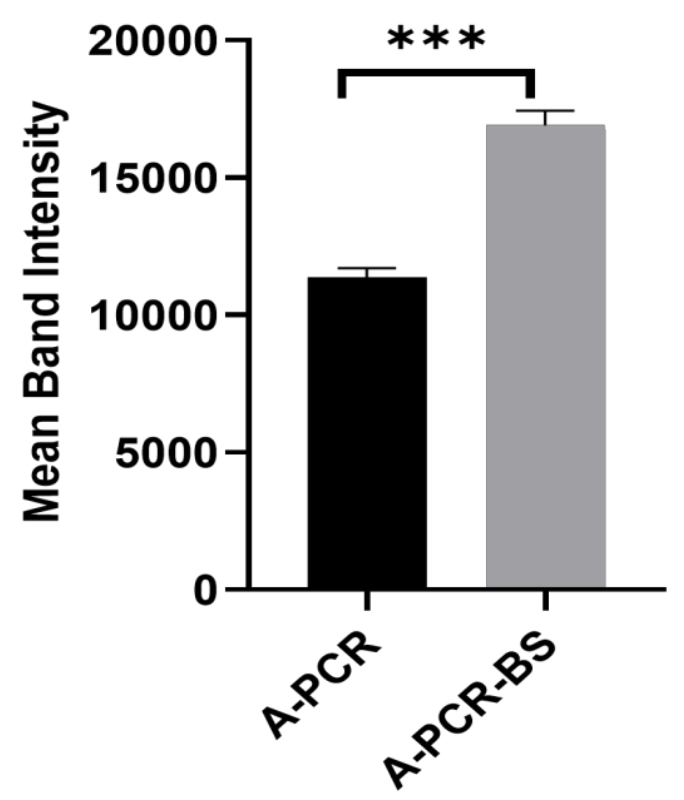


Table 1: Yield of ssDNA generated by our method

\begin{tabular}{ccccc}
\hline $\begin{array}{c}\text { ssDNA } \\
\text { generation } \\
\text { method }\end{array}$ & $\begin{array}{c}\text { Amount of ssDNA } \\
\text { recovered (nM) }\end{array}$ & Time (hr) & Cost (USD) & $\begin{array}{c}\text { Amount of ssDNA } \\
\text { recovered by Svobodova et } \\
\text { al (nM) }\end{array}$ \\
\hline A-PCR & $450 \pm 10.2$ & $1 \mathrm{hr}$ & 7 & $106 \pm 39$ \\
A-PCR-lambda & $700 \pm 11.3$ & $1.5 \mathrm{hr}$ & 8 & $274 \pm 23.8$ \\
exonuclease & & & & \\
A-PCR-biotin- & $820 \pm 19.2$ & $1.5 \mathrm{hr}$ & 14 & - \\
streptavidin & & & & \\
\hline
\end{tabular}


Table 2: Comparison of the optimization of the parameters in the asymmetric PCR

\begin{tabular}{lcccc}
\hline \multicolumn{1}{c}{ Parameters } & This study & $\begin{array}{c}\text { Citartan et } \\
\text { al., } 2012\end{array}$ & $\begin{array}{c}\text { Tabarzad } \\
\text { et al., } 2014\end{array}$ & $\begin{array}{c}\text { Heiat et } \\
\text { al., } 2017\end{array}$ \\
& & 20 & 20 & 20 \\
\hline PCR cycles & $50: 1$ & $20: 1$ & $15: 1$ & $50: 1$ \\
Primer ratio & 56.9 & - & 64 & 59 \\
Annealing temperature $\left({ }^{\circ} \mathrm{C}\right)$ & 1.6 & - & 5 & 2 \\
Template concentration $(\mathrm{ng} / \mu \mathrm{L})$ & & - & 0.25 & - \\
Mg ${ }^{2+}$ /dNTP concentration $(\mathrm{mM})$ & $0.2 / 1.5$ & - & - & - \\
Taq Polymerase $(\mathrm{U})$ & $2.5 \mathrm{U}$ & & & \\
\hline
\end{tabular}




\section{Reviewers:}

1. Dr. Baofeng Yu,

Department of Biochemistry and Molecular Biology, Shanxi Medical University,

Taiyuan, Shanxi 030001, China

Email: shanxiyangcheng@126.com

2. Dr. Endang W. Bachtiar

Oral Research Science Center, Faculty of Dentistry, Universitas Indonesia, Jakarta, Indonesia

Email: endangwiniati08@gmail.com, endang04@ui.ac.id

3. Dr. Gwo-Bin Lee

Department of Power Mechanical Engineering, National Tsing Hua University, Hsinchu, Taiwan

Email: gwobin@pme.nthu.edu.tw 